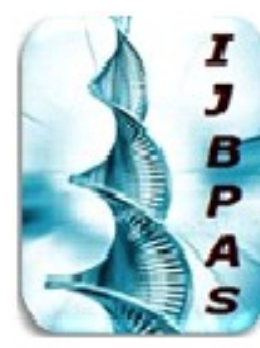

International Journal of Bhology, Pharmacy and Allied Sciences (IJBPAS) 'A Bridge Betusen Caboratory and Q Quder'

WwW.iibpas.com

ROLE OF REMITTANCES IN POVERTY REDUCTION: A MICRO EVIDENCE FROM PAKISTAN

\title{
FAROOQE $\mathbf{H}^{1^{*}}$, SUBHAN $\mathrm{S}^{2}$, AKBAR $\mathrm{M}^{3}$ AND KHAN $M^{4}$
}

1: Lecturer Department of Economics, National University of Modern Languages, Islamabad, Pakistan

2: Assistant Professor Department of Economics

National University of Modern Languages, Islamabad, Pakistan

3: $\mathrm{PhD}$ (Scholar), Department of Economics, National University of Modern Languages, Islamabad, Pakistan

4: PhD (Scholar), Department of Economics, Federal Urdu University, Islamabad, Pakistan

*Corresponding Author: E Mail: haidar5055@gmail.com; Phone: +92-3004123355

Received 22 ${ }^{\text {nd }}$ Aug. 2019; Revised $7^{\text {th }}$ Oct. 2019; Accepted $7^{\text {th }}$ Jan. 2020; Available online $1^{\text {st }}$ June 2020

https://doi.org/10.31032/IJBPAS/2020/9.6.5036

\section{ABSTRACT}

This research study investigated the effect of foreign remittances on poverty level. A method of primary data source has been adopted for this purpose. Through a comprehensive questionnaire data was collected. District lower Dir is selected for survey due to its significant importance regarding foreign migration and incoming remittances. The outcome shows that remittances have significant and progressive relationship with the reduction of poverty. Incoming remittances enhance the income status of remittance recipient households, which eliminate the poverty. Moreover results reveal that $76 \%$ in the remittance recipient households are non-poor while only $8 \%$ non-recipient households are non-poor. It is concluded that remittances contribute positively to reduce poverty. If a family receives foreign remittances then it is more probable to be nonpoor and fewer chances to be a poor. When a family shifts from remittance recipient status to a non-recipient status its probability of poor status also increases.

Keywords: Remittances, Poverty, Logit and Probit 


\section{INTRODUCTION}

Foreign remittances is the most important and influential financial source for developing countries. Remittances inflow contributing progressively to poverty elimination and economic growth. It enhances the welfare of the society by increasing the income status of the remittance recipient households. Moreover it expands the health services, helpful in providing good educational facilities and create opportunities for investment. The incoming foreign remittances provided a big contribution to Pakistan foreign exchange earnings. [1] argued that a substantial amount of remittances received by Pakistan which is helpful to stabilize the balance of payment position, to reduce the deficit of current account, contribution well to welfare and economic development.

In the last two decades from 20002019 remittances of Pakistan increased considerably from US\$ 1 billion to US\$ 22 billion (SB, 2019). Foreign remittances contributed $5 \%$ average per year to GDP from 1975-2015 to Pakistan economy [2]. The quantity of overseas migrant's also enlarged over the period of time from 3 million in 2002 to almost 10 million in 2018 (2018, BEOE). After foreign direct investment remittances ranked as a second highest source of incoming external finance. In last three decades worker remittances increased sharply to Africa, Asia, Pacific region and Latin America, which is measured like a major contribution to economic growth. Due to this considerable financial inflows less developing countries are more connected with international financial setup and getting more financial capital [3].

In year 2015 remittance flows were estimated one of the top global financial flows, which prolonged to about US\$ 400 billion. Remittances are contributing a key share to GDP for several developing economies. The contribution of remittances to GDP was estimated almost $5 \%$ to the highest 30 remittances receiving countries in year 2015.These influential effects were measured highly important and higher in magnitudes from foreign direct investment and official development aid. It also has a strong influence on the demand and supply of labor force of migrant producing economies [4].

[5] argued that remittances is positively correlated with poverty elimination. A big share of incoming remittances is utilized for investment and consumption related goods like utilities, durables, health related expenditures and 
housing facilities. A $10 \%$ growth in remittances flow leads to reduce poverty by $5 \%$ on average. According to [6] remittances flow directly increases the income status, consumption status and create the investment opportunities. These developments further promote welfare aspects and reduce poverty level. It is suggested by [1] that remittances contribute strongly to economic development and poverty alleviation. The role of remittances is more effective in developing economies like Pakistan.

\section{Overview of Poverty}

Poverty is a well-known global phenomena, it has many faces like unavailability of food, lacking health facilities and housing facilities. It also exists in the form of lacking educational facilities due to little income resources, lacking employment opportunities and future insecurity. Poverty is miscarriages of child in the early birth, sickness by using unclean water and a lesser amount of food. In modern world poverty is also explained in the form of lacking freedom, lacking representation, incompetence, ineffectiveness and powerlessness. According to [7] poverty is the incompetence to avail a nominal standard of living, in the science of insufficient income capabilities which is required for the basic needs of life.
Worldwide, almost $90 \%$ of the deprived and poor population live in the developing region of Asia and Africa. A big share of these people lives in different rural parts of the developing countries, which almost three out of four [8]. A big reason behind the poverty is agriculture based economies and rural set up. Where most of the people are facing the problems like scarcity of food, clothing, health care, education, housing and human rights. Pakistan ranked the sixth most populated country in the globe with the growth rate of $1.9 \%$ and total population was about 200 million in 2017. The 59\% of county's population exist in the rural regions while $41 \%$ in the urban region (Pakistan Economic Survey, 2017).

[7] recommended that Pakistan has made a considerable improvement in the reduction of poverty, particularly in the last fifteen years 2001-15. This progress of poverty reduction was estimated about $10 \%$ from year 2001-15. The rate of infant mortality was also reduced from 86 to 80 out of 1000 in the time period of 2005-15. Moreover the maternal mortality also goes down to 178 from 249 out of 100,000. The educational sector also developed due to increase in school enrolment and literacy rate improved from $53 \%$ to $58 \%$. But still quality 
education and some basic facilities need more attention. Higher population growth rate is challenging task for government to provide all the related services for human development progress [7].

The research study carried out in District Lower Dir having a substantial importance related migration and foreign remittances. Dir Lower is one highest migrant producing and remittances receiving Districts in Pakistan. According to the data of Pakistan Bureau of Emigration and Overseas Employment (BEOE) Pakistan produces almost 10 million migrant workers from 1981-18, Dir Lower contributing about 0.352 million migrant worker to country directory. Additionally, Lower Dir District is on the top of the list Khyber Pakhtunkhwa province followed by Mardan and Peshawar and $5^{\text {th }}$ largest after Karachi, Sialkot, Lahore and Rawalpindi in the year 2018 (BEOE, 2018). After analyzing the previous literature we have found some studies at national and local level which have worked in different features of remittances and migration. But this study differentiates all other available studies with respect to size of sample, up to date comprehensive literature, empirical analysis and descriptive analysis.

\section{LITERATURE REVIEW}

This section analyzed the previous literature regarding foreign remittances and its impact on poverty reduction. These researchers analyzed the relationship of foreign remittances on poverty reduction with different point of views. Some researchers acknowledged that foreign remittances have a positive relationship with poverty reduction. But some of the researchers also analyzed that it may have negatively connected to poverty reduction due to nonproductive uses of foreign remittances.

[9] examined that foreign capital inflow i.e. foreign aid, FDI, foreign debt and remittances are positively correlated to poverty in case of Pakistan. The results suggested that inflows of foreign capital have a positive association with poverty level. It is argued that an increase in the inflows of foreign capital increases the level of poverty directly and upturn infant mortality rate indirectly. The study submitted that due to nonproductive uses of foreign capital inflows it is not contributing to poverty reduction.

[10] studied that foreign remittances reduces the income inequalities and poverty level from both side of micro and macro level. A $100 \%$ increase in the remittances inflow reduces the $36 \%$ of poverty and $10 \%$ income inequality. The study suggested that 
remittances inflow and household saving ratio have a positive relationship. It is concluded that migration to the Middle East is positively connected with poverty alleviation while in case of North America and European states the relationship is negative with income inequalities and poverty reduction.

[11] examined that remittances inflow has a positive relationship with migrant family life style, social standings and educational progress of children. Remittances also contribute positively by changing the behavior of relative and friends with remittances recipient family. It also motivates real estate investment, micro level businesses and investment in agriculture side. The study observed that main motive behind overseas migration was weak economic situation, unemployment, the passion of competition and poor social status.

[12] examined that remittances increase $30 \%$ of the probability of a non-poor status. The analysis summarized that incoming remittances boost up income per capita of the family and furthermore it contributes to poverty elimination at both urban and rural areas of Pakistan. Remittances inflow plays a vital role to support and stabilize the economy at both micro \& macro level. Additionally it also provides support to government policy measures regarding poverty reduction.

\section{RESEARCH METHODOLOGY}

Methodology of this research work is organized in this section. This section has been divided into further three sections i.e. universe of study, sampling and the model, that are discussed in more details as follows.

\section{Universe of the Study}

The District of Lower Dir is considered for a research study that is one of the thirty five Districts of Khyber Pakhtunkhwa provinces after the merger of former FATA districts. Lower Dir is placed on the north west of Pakistan nearby Afghanistan border. According to population census 2017 District Lower Dir was estimated having population about 1.4 million ranked $9^{\text {th }}$ most populous district in Khyber Pakhtunkhwa.

\section{Sampling}

In sampling procedure data were collected from district Lower Dir. A 403 families were interviewed, almost half of these families are remittance recipient and half of these are non-recipient household in the whole sample size. Household data was collected from 35 villages with the help of questionnaire to obtain the appropriate information in the years 2013-14. Randomly 
at least 50 household samples were collected from all of the seven tehsils.

\section{The Model}

The available methodology that has been used in previous literature was adopted for this study. This model is used by [10] to investigate the impact of remittances on poverty elimination \& income disparities. We have estimated this model to investigate our dependent variable, household poverty to investigate the role of remittances in the poverty reduction.

$\mathrm{Y}_{\mathrm{i}}=\beta_{0}+\beta_{1} \mathrm{RMT}+\beta_{3} \mathrm{X}_{\mathrm{i}}+\varepsilon_{\mathrm{i}}$

Where $Y_{i}$, denotes household poverty which is our dependent variable. RMT represents household remittances, $\mathrm{X}_{\mathrm{i}}$ denotes control variables which are income of the family, income earners in family, agriculture related production, livestock, parents education (father \& mother), and number of children and family size.

The dependent variable shows a binary $(0,1)$ response that a household is poor or non-poor. Due to a binary repose of dependent variable and nonlinear relationship, we used the nonlinear regression models of Logit and Probit for estimation.

\section{RESULTS AND DISCUSSIONS}

The results have been arranged into two sections i.e. descriptive and empirical analysis. In the following both are explained in more details.

\section{Descriptive Analysis}

This section provides summary statistics in tables. Comparative analysis is given with detail for both type of families i.e. remittance recipient and non-recipient household. To evaluate the role of remittances, information is given separately for both type of households and to analyze the difference and gap between them.

Table 1 provides information about poverty level that how many among the remittances recipient and how many among the nonrecipient families are above the line of poverty or having non-poor status. The analysis of poverty is based on [2] definition i.e. if a person has less than two dollar daily income is considered poor. On the other hand, if a person has more than two dollar daily income is considered non-poor. Results explain that $76 \%$ of the remittance recipient families are above the line of poverty while $8 \%$ of non-recipient families exist above the line of poverty. The collective average proportion for overall sample size for both families is $42 \%$ which exist above the line of poverty. It is summarized that overseas remittances show a positive relationship with poverty reduction, if a family receives 
foreign remittances then that family has a greater possibility to be a non-poor.

Table 2 explains details about house quality or type owned by a household. House quality is divided into four categories from highest to lowest. The last row of table explains the average availability of rooms in the home for both type of families. In the highest quality of house i.e. cement made house, remittance recipient families show a greater presence of $61 \%$ and non-recipient families show lesser presence of $32 \%$. While on other hand nonrecipient families show a higher presence of $44 \%$ in a mud made house. Remittance recipient families own near to average 6 rooms in the house and non-recipient families own average 4 rooms in the house. It is conclude that remittance recipient families have good housing facility with respect to non-recipient families.

\section{Regression Analysis}

Outcomes obtained from Logit and Probit regression analysis. Thiel's Benchmark Criterion is adopted for the analysis of regression. On the basis of Thiel's Benchmark Criteriaall of those variables which are insignificant are dropped. This procedure of estimation is called from general to specific approach. In the following obtained results and interpretation are explained.

Table 3 shows the marginal effects of independent variables according to dependent variable. Results of both models are nearly the same. The dependent variable is household poverty that a family is above the line of poverty or below. Explanatory variables are remittances (RMT), monthly income (MI), income earners (IE), father education graduate and master (FEGM), mother education graduate and master (MEGM), numbers of children ( $\mathrm{NCH})$ and family size (FS).

Foreign remittances is the most significant and a policy variable of this research work, it explains that a family receives remittances or not. Result shows that if a family receives remittances from abroad its probability of being non-poor status increased by $49 \%$ in Probit and 52\% Logit model. In simple words foreign remittances decreases the chances of poverty $49-52 \%$ in both the models. If a family receives overseas remittances then that household has greater chances to be non-poor. 
Table 1: Percentage Poverty Details for Both Type of Families

\begin{tabular}{c|cc|cc|cr}
\hline \multirow{2}{*}{ Poverty Status } & \multicolumn{2}{|c|}{$\begin{array}{c}\text { Remittance recipient } \\
\text { households }\end{array}$} & \multicolumn{2}{c}{ Non-recipient households } & \multicolumn{2}{c}{ Total } \\
\cline { 2 - 7 } & Numbers & Percentage & Numbers & Percentage & Numbers & Percentage \\
\hline Non-poor status & 154 & $76 \%$ & 16 & $8 \%$ & 170 & $42 \%$ \\
Poor Status & 49 & $24 \%$ & 184 & $92 \%$ & 233 & $58 \%$ \\
\hline Total & 203 & $100 \%$ & 200 & $100 \%$ & 403 & $100 \%$ \\
\hline
\end{tabular}

Table 2: House Quality Details for Both Type of Families

\begin{tabular}{ccc} 
House quality & $\begin{array}{c}\text { Remittance recipient } \\
\text { households }\end{array}$ & $\begin{array}{c}\text { Remittance non-recipient } \\
\text { households }\end{array}$ \\
\hline Cement made house & $61 \%$ & $32 \%$ \\
Mixed of mud and cement & $21 \%$ & $22 \%$ \\
Iron sheet roof house & $2 \%$ & $2 \%$ \\
Mud made house & $16 \%$ & $44 \%$ \\
\hline Number of rooms in the house & 5.71 & 4.10
\end{tabular}

Table 3: Logit and Probit Results for Household Poverty

\begin{tabular}{ccc}
\hline Explanatory Variables & Logit Model & Probit Model \\
\hline RMT (remittances) & $\mathbf{0 . 5 1 6}$ & $\mathbf{0 . 4 9 4}$ \\
MI (monthly income) & $\mathbf{0 . 0 4 0}$ & $\mathbf{0 . 0 1 6}$ \\
IE (income earners) & $\mathbf{0 . 1 8 0}$ & $\mathbf{0 . 0 7 6}$ \\
FEGM (father education graduate and master) & $\mathbf{0 . 2 2 7}$ & $\mathbf{0 . 1 3 8}$ \\
MEGM (mother education graduate and master) & $\mathbf{0 . 4 0 8}$ & $\mathbf{0 . 2 5 5}$ \\
NCH (numbers of children) & $\mathbf{- 0 . 0 0 1}$ & $\mathbf{- 0 . 0 0 3}$ \\
FS (family size) & $\mathbf{- 0 . 2 3 9}$ & $\mathbf{- 0 . 0 9 7}$ \\
Constant & $\mathbf{- 0 . 3 8 4}$ & $\mathbf{- 0 . 4 0 4}$ \\
\hline
\end{tabular}

The second most important independent variable is income of the family with respect to poverty. The results reveal that when we increase one unit $(1000$ Pakistani rupees monthly income), its probability of being non-poor status increases by $2 \%$ in Probit and $4 \%$ in the Logit model. It clearly explains that a family income plays very significant role in the reduction of poverty. When the family income rises then family can easily fulfill the essential needs of life. This increase in the family income will lead to raise the life standard of that family. In simple words, we can say that monthly income has negative association with poverty level, if monthly income increases the poverty level will decline.

Similarly, the earners of income in the household also play an important contribution to poverty elevation. The results show that one unit (one income earner) upturn in the family earner's list will reduce the possibility of poor status by $8 \%$ in Probit model \& $18 \%$ in the Logit. It is concluded that more income earners in household will reduce the possibilities of being poor status.

Parental education also plays effective role in the poverty elimination. Father's education with the category of graduate and master as compared to no- 
formal educational status increases the likelihood of non-poor status by $14 \%$ in Probit and 23\% in Logit model. Whereas for mother's education with the category of graduate and master as associate to no-formal educational status also increases the possibility of being non-poor status by $26 \%$ in Probit and $41 \%$ in Logit model. In the study area, mothers with good educational status that is graduation and master level education are mostly on jobs which contribute towards poverty reduction. It is concluded that parental education plays very important role in poverty elimination.

The children numbers between 5-18 years of age is negatively connected with family non-poor status. A one unit increase in the number of children will increase the probability of poor family status. When the number of children increases, it increases the poverty level, because of the increase in dependency ratio and increase in the educational expenditures. Family size shows a negative correlation with non-poor family status. If the member of family increases, the family moves from a status of non-poor to poor status.

It is summarized that remittances inflow, monthly income, income earners shows a positive impact on poverty elimination. Highest categories of parental education i.e. graduate and master also shows a positive relationship with the elimination of poverty. Additional, results revealed that number of children and family size show an inverse relationship with the reduction of poverty.

\section{CONCLUSION}

This research work examined the effect of foreign remittances on poverty reduction. From results we conclude that only 8 percent of the remittance nonrecipient families are above the poverty line while $76 \%$ of the remittance recipient families are above the poverty line. This ratio explains that remittance inflows have a positive effect on poverty alleviation, if a family receives foreign remittances then that family has a greater chance to above the line of poverty. While in case of remittance nonreceiving families, its chances of poor status, increases. Results also show that family size has a negative relationship with non-poor status. If the family size increases the chances of being poor also rises. Family income shows a positive association with the reduction of poverty. When family income rises the probability of poor status decreases. Likewise the number of income earners also shows a positive relationship with poverty elimination. The parental educational level also contributing effectively to poverty 
elimination, if parents are well educated then that family is more probable to exist above the line of poverty.

\section{POLICY IMPLICATIONS}

This study summarized that remittances contributing positively to poverty elimination. But still there is some inefficiencies and difficulties which needed further attention and consideration from policy related government authorities. These policy steps will be more effective for the development of household level and at national level. This study reveals that mostly migrants have a weak educational status and low level of technical abilities. Consequently, these weak educational abilities poorly affect their income. It is required from government to provide well technical and formal educational facility to these migrants and youngsters, to increase their productivity and output.

It is recognized in the study that the major share of the incoming remittances spent for nonproductive purposes, capital intensive and luxury goods, like construction of new houses, real estate, home appliances, vehicles, etc. If this huge amount is utilized or channelized to labor intensive sector, then it will generate a lot of jobs opportunities in the economy. Hence, it is very essential and need of the day to develop a proper policy to utilize these massive amounts of remittances for the betterment of the country.

There are also some problems in the study area i.e. less portion of agricultural land, lack of industries, rarer business opportunities, less job opportunities in both government \&private sector. Therefore, mostly people prefer foreign migration for better future. It is needed as a policy to develop structure for businesses, industries, mining, power generation and tube wells for agriculture side. This will be helpful by providing job opportunities locally at their door steps and the prosperity might become possible at long period of time.

The female participation in the study is very low. Due to lesser educational facilities for female and traditional life style, where for females it is unusual to work and also lesser job opportunities. There it is needed from government authorities to make available improved educational infrastructure related to formal education, technical education and vocational education on their doorstep. So that they can contribute to the economic prosperity of their families.

\section{REFERENCES}

[1] Javid, M., Arif, U., \& Qayyum, A. (2012). Impact of remittances on economic growth and 
poverty. Academic Research

International, 2(1), 433.

[2] World Bank (2015). Migration and remittances: Recent developments and outlook. Special financing for development, Migration and Development Brief No. 24.

[3] Bhattacharya, M., Inekwe, J., \& Paramati, S. R. (2018). Remittances and financial development: empirical evidence from heterogeneous panel of countries. Applied Economics, 1-14.

[4] Chami, R., Ernst, E., Fullenkamp, C., \&Oeking, A. (2018). Are remittances good for labor markets in LICs, MICs and Fragile states? Evidence from cross-country data.

[5] Peković, D. (2017). The effects of remittances on poverty alleviation in transition countries. Journal of International Studies Vol, 10(4).

[6] Irfan, M. (2011). Remittances and poverty linkages in Pakistan: Evidence and some suggestions for further analysis. PIDE Working Papers \& Research Reports, 2011-78.

[7] World Bank Group. (2016). Pakistan development update making growth matter. (2016). World Bank Group.

[8] Pervez, S., \& Rizvi, S. B. U. H. (2014). An empirical analysis on determinants of poverty: A cointegration analysis. Issues, 2(1).

[9] Ali, M., Nishat, M., \& Anwar, T. (2009). Do foreign inflows benefit Pakistani poor? The Pakistan Development Review, 715-738.

[10] Mughal, M., \&Diawar, B. (2010). Impact of remittances on inequality and poverty: Macro and microevidence from Pakistan. Centre d'Analyseet Traitement Théorique des Données Economiques, Université de Pau et des Pays de l'Adour, France.

[11] Muhammad, N., Ahmad, N., Shah, M., Alam, I., \& Jawad, M. (2010). The impact of foreign remittances on the socio-economic conditions of households. Sarhad J. Agric, 26(1), 141-145.

[12] Iqbal, A. (2013). Impact of foreign remittances on household poverty in Pakistan: evidence from household data. Master Thesis UMB School of Economics and Business Norwegian University of Life Sciences. 